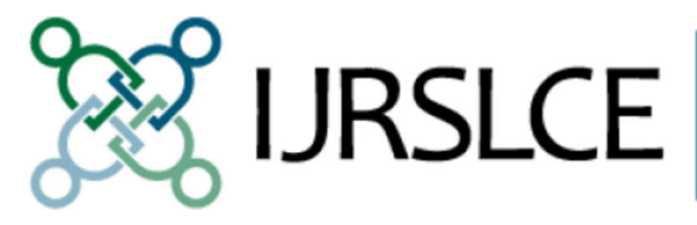

International Journal

for Research on

Service-Learning \&

Community Engagement

\title{
The Role of the School Counselor in Service-Learning
}

\author{
María Lourdes García López \\ Pilar Aramburuzabala Higuera \\ Rosario Cerrillo Martin
}

This article was originally published at:

https://journals.sfu.ca/iarslce/index.php/journal/article/view/270/180

Recommended Citation

García López, M. L., Aramburuzabala Higuera, P., Cerrillo Martin, R. (2016). The role of the school counselor in service-learning. International Journal of Research on Service-Learning and Community Engagement, 4(1), 355-365. 


\title{
The Role of the School Counselor in Service-Learning
}

\author{
García López, María Lourdes. \\ Aramburuzabala Higuera, Pilar. \\ Cerrillo Martin, Rosario. \\ Autonomous University of Madrid
}

\begin{abstract}
In recent years, the perception of the role of school counselors has undergone a significant change. Within this framework, it is particularly relevant to know the role of the school counselor in service-learning. This is the objective of the case study that is being carried out at a secondary school in Madrid that is considered a reference point in the use of this methodology. Results of the study show the pedagogical leadership of these professionals, who can act as promoters, coordinators, consultants, developers, and ambassadors of S-L in their schools.
\end{abstract}

Keywords: role, school counselor, service-learning

\section{Theoretical framework}

There is a wide range of literature on school counseling, specifically on the activities of school counselors, which allows to deepen in their role.

In this paper, the school counselor is a teacher who performs a specialized role in the field of counseling, which is a process of support and advice for the development of educational goals.

After a long trajectory, school counseling in Spain has achieved prestige and professional recognition (Domingo Segovia, 2006). The implementation of the counseling department in secondary schools was one of the factors anticipated to help solve problems encountered in secondary education. Although this school body was initially perceived as a necessary but seldom requested support service, over time it has earned its place not only as an additional resource for the school, but also as a key factor in its process of improvement.

The counselor, as an advocate for quality education, must not only adapt to change, but must promote it. "Being a change agent is to be a facilitator, mediator, and promotor of counseling and education throughout life" (Martínez Clares \& Martínez Juárez, 2011, p. 257). That is why thinking on this role involves questioning the way in which the professional counselor can contribute to creating a culture of improvement, thereby building capacity for change and optimizing learning in the school community so that the quality of education is guaranteed (Martínez Garrido, Krichesky \& Garcia Barrera, 2010).

Literature on educational change looks at the role of counselors in the processes of support and advice to schools regarding plans for improvement and innovation (Bolivar \& Romero, 2009; Calvo, Haya, \& Susinos, 2012; Domingo Segovia, 2004; Domingo, Fernandez, Barrero, 2014; Murillo \& Krichescky, 2012; Santana Vega, 2010). Their training on pedagogical, psychological, strategic, and mediative aspects allows them to perform their role in in collaboration with other members of the school community (Martínez Garrido et al., 2010). It is, therefore, a relevant figure for making real innovation and improvement proposals related to the coordination and advisory functions, such as the implementation of service-learning methodology.

In this context, service-learning is seen as one of the innovative methodologies that enhances quality teaching (Lucas \& Martínez Odriá, 2012). This methodology enriches the educational process and helps to achieve its objectives. The two elements, learning and service, form a combination that contributes to promoting quality and improvement, where learning 
improves the quality of service and vice versa (Eyler, Giles, \& Braxton, 1997).

Service-learning provides an ideal platform for the development of perceptions and attitudes that are favorable to social transformation, having teachers, students, and the community as catalysts of change (Smith-Tolken \& Williams, 2011) and social justice.

The purpose of education for social justice is to provide transformative experiences related to issues of oppression and imbalance of power. In a social context that is considered to be in crisis in all dimensions (economic, social and moral), any practices that focus on social justice, such as service-learning, are key for projecting social values such as cohesion and citizenship. Aramburuzabala, Cerrillo, \& Tello (2015, p 90) describe service-learning as "a pedagogical strategy that engages students in service for improving understanding of academic concepts through experiential learning, and as an instrument of social and political reform that promotes sustainable development and social justice".

The conceptualization of service-learning as an original combination of two known elements, learning and community service (Puig, Batlle, Bosch, \& Palos, 2007), makes it an interesting content for school counseling. Nelson (2007) points out that school counselors play an important role in promoting actions for students' development. In line with that, this paper proposes the idea that service-learning can be a vehicle to affect a large number of students in a positive way.

There are numerous studies on the roles and functions of the counselor (Boza Carreño, Toscano, \& Salas, 2009; Celorrio, 2004, Hernando \& Montilla, 2009; Sobrado \& Sanz, 1998; Stelzer, 2003) that agree on the multiplicity and lack of definition of the tasks performed by these professionals. There is an excess of functions and tasks related to counseling, evaluation, and to the design of programs that are directly related to the counselor's role (Loizaga, 2005).

Research on service-learning is increasing progressively. Some studies address issues related to teachers who use this methodology. While most of the experiences take place in higher education, Blakey, Theriot, Carrell, \& Sattler (2015) state that these can be a reference for development in other levels of education.

There is very little scientific literature that relates service-learning to counseling. In this regard, Steen, O'Keefe, Griffin, \& Routzahn $(2012$, p. 4) state that an Internet search showed that articles on service-learning and guidance counseling are almost nonexistent:

"One article found to address social skills with elementary students using service-learning (...) Another article (...) incorporated service-learning in a comprehensive school counseling program (...). Despite these two examples, there remains a need for additional school counseling programs to integrate service-learning into its programming efforts"

There is, however, some research that focuses mainly on studies on the effects of servicelearning results on the training of school counselors (Jett \& Delgado-Romero, 2009, Dockery, 2011). Publications such as A Practical Guide to Service Learning: Strategies for Positive Development in schools, by Wilczenski \& Coomey (2007), present the theory and some practical ideas for the implementation of service-learning by school counselors.

\section{Purpose of the Study}

The research presented here was undertaken in order to establish the roles developed by the school counselor in a service-learning program at a secondary school. This research question leads to more specific questions: Is there a relationship between service-learning and school counseling? If so, what is the role of the school counselor in the development of servicelearning?

This work is part of a larger study that aims at examining the relationship between servicelearning and school counseling, and identifying the role of counseling in the service-learning program of a secondary school.

\section{Participants and Methods}

Given that the purpose of this study is not to generalize data but to have a closer look at the educational reality in order to understand it, case study was selected as the methodology for 
describing, analyzing, and understanding the role of the counselor as a facilitator of servicelearning experiences.

The case selection was intentional due to its thematic interest. Among other centers in Madrid where service-learning is used, the Miguel Catalán secondary school was selected, taking the following criteria into account:

- The trajectory of the center on the use of service-learning

- The trajectory of the school counselor

- The relationship of the counselor with service-learning

In addition to the counselor, who is considered the key informant in this research, other participants in the study are the school's principal, teachers, students, families, and social organizations that are part of the educational community and are familiar with the school's service-learning program.

Focused individual and group interviews were conducted and open-question surveys were used for gathering information. It is possible to establish the development of school counseling in service-learning through the participants' discourse. Individual interviews were conducted with the counselor, the school principal, teachers who participated in the service-learning program, and community groups. Focus-group interviews were conducted with students and families because this technique is less intimidating for these participants and it shows their opinions and statements (Simons, 2011).

In this study, an open-ended questionnaire is used with teachers because they are considered essential mediators in the teaching-learning process and in the development of service-learning projects within their subjects. Informants do not necessarily need to have actually participated in service-learning. The only established criterion is being a member of the teaching staff.

Information was collected throughout the period of stay of the researcher at the school. It was carried out through various media, including audio and images. In addition, notes were taken, after permission was granted by those involved.

Fieldwork was conducted during a four-month period, from September to December 2015, during the first quarter of the school year, at least once a week. During that time, the researcher adjusted her work to the activity of the school and especially to the activity of the counselor, as the main informant in this study.

In this paper, the categories of analysis are in line with the objectives of the research. They are predetermined and constitute the central categories. These categories will become saturated as of a number of subcategories emerge from the analysis of data sources.

Table 1. Categories of analysis. Perceptions of participants in the study.

Name of the category

Relationship between service-learning and school counseling

Roles of the counselor

\section{Description of the category}

Explicit connection between counseling and servicelearning mentioned by participants

Functions and actions played by the counselor in the service-learning program

In this paper, grounded theory and ATLAS.ti were used to perform a grounded theoretical approach that fits in with the data. ATLAS.ti facilitated management of the information collected through interviews and questionnaires, and the methodological triangulation. It was used for coding-recoding the analysis, and also for transcribing the information.

Following the ethical standards of qualitative research proposed by Norena, AlcarazMoreno, Guillermo, \& Rebolledo-Malpica (2012), all informants agreed to participate in the study. An authorization for carrying out the research was requested of the school principal in the first phase. He was informed about the research objectives and issues relating to the rights and 
responsibilities of participants in the study.

\section{Results}

\section{Service-learning, a track for developing school counseling}

One of the objectives of this case study is to determine whether participants in service-learning experiences perceive a relationship between the development of service-learning and school counseling; and, if so, what kind of relationship they perceive.

The results show that all participants clearly establish the relationship between servicelearning and school counseling, from which it can be deduced that service-learning in this school is within the framework of school counseling, insofar as it constitutes a means for its development and it facilitates the establishment of the roles and functions of the school counselor.

Table 2. Sub-categories and participants: Relationship between service-learning and school counseling.

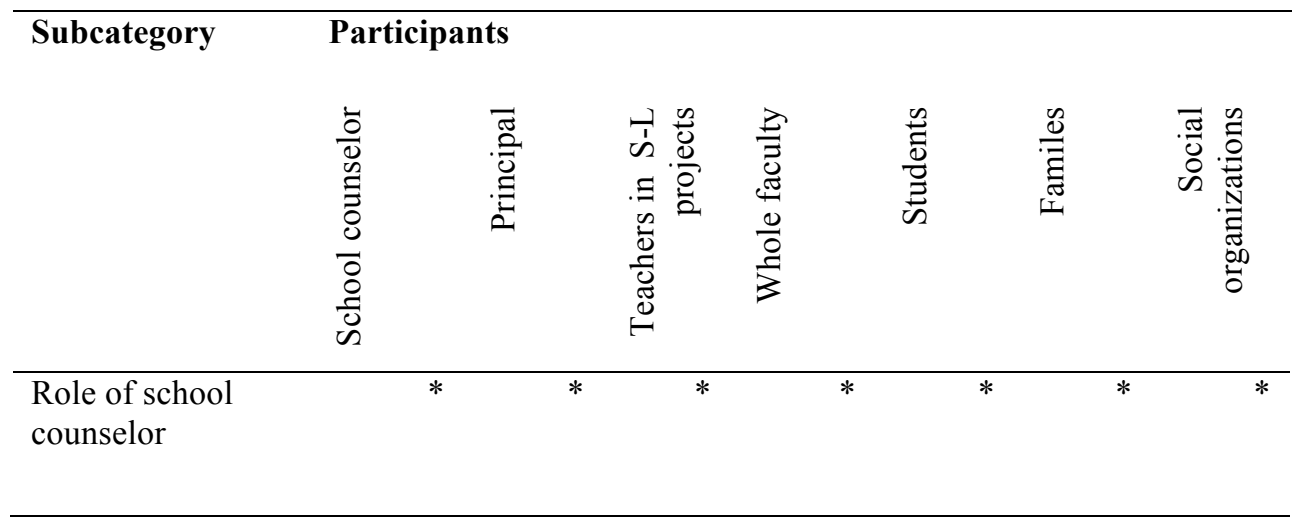

Participants in this study also mention the relationship between service-learning and school counseling based the role of counselor. In this they concur with Nelson (2007), who points out that, as an intervention, service-learning is a smart option for developing programs of school counseling.

The counselor establishes the connection between service-learning and his functions to the extent that it is a tool for developing them, and he emphasizes activities related to coexistence and intervention in the environment. This view is similar to that of the representatives of social entities, who also consider service-learning as a way to focus the work of the counselor.

"I think so. But that doesn't mean that he should be the only person who coordinates it. But (...) I think that it's an opportunity for all counseling tasks. It's another way to approach them; it's an interesting way to approach them [...]" (Counselor).

"I think so. For me, yes, he is the key. The idea is not to underestimate a math teacher, but it makes no sense that a math teacher decides to use that subject for coordinating all service-learning projects in the school. School counseling can do it" (social organization_2).

On the other hand, for teachers, the relationship between service-learning and the school counselor is based on the fact that they consider him as an advisor, promoter, and coordinator of the development of projects at the school.

"Total, the relationship is total; that is, the issue of training in order to see how we can do it, how to design it and all, has to do with the counselor [..]" (Teacher involved in 
service-learning_3).

"Yes. He is the link between all the different projects and subjects" (Teaching staff_11).

In the same vein, students and families highlight the counselor's role as facilitator and adviser in the development of the projects. From this, it can be concluded that rather than primarily "putting out individual fires", school counselors have the potential to work globally improving the educational experiences of students through service-learning programs (Nelson, 2007).

"Yes, because if, for example you have any queries about any of the projects, you always go to the counselor to ask that question" (Student_4. Compulsory Secondary Education).

"[..] It's true that counseling and service-learning (...), all that makes them more human. And maybe at home, not because parents don't know how to do it, but because they don't have time (...), here with counseling, with the school, they really learn a lot by doing these things" (Family_2).

Finally, it is important to mention the relationship between the service-learning program and the school counselor that is established by the school principal. According to him, the counselor has the personal competencies for acting as a facilitator of proposals.

"From a professional and personal point of view our counselor (...) he has an incredible ability to create and organize, and therefore for me he is essential. I don't care if he is from the counseling department or from another one; I would put him on it wherever he was. But in any case, I believe that the counseling department is essential" (School principal).

\section{Multiple roles of the counselor in service-learning}

According to the results of this research, informants agree that the counselor develops several roles in the service-learning program of the school. The roles identified in their discourse are: promoter, coordinator, developer, consultant, advisor, ambassador, and educational leader.

The counselor and teachers concur in all the identified roles. This could be due to the collaborative work that he promotes and carries out for the development of service-learning projects in the school. This consensus is shown in the following table:

Table 3. Sub-categories and participants. Roles of the counselor in the service-learning program.

\begin{tabular}{|c|c|c|c|c|c|c|c|c|c|}
\hline \multirow[t]{2}{*}{ Subcategories } & & & & & & & & \multicolumn{2}{|c|}{ Participants } \\
\hline & 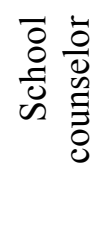 & 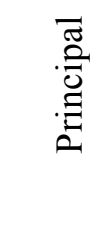 & 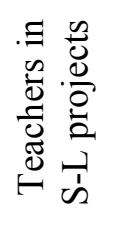 & 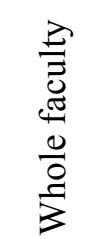 & & $\begin{array}{l}\frac{\tilde{O}}{\tilde{D}} \\
\stackrel{0}{\tilde{E}} \\
\tilde{n}\end{array}$ & & 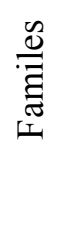 & 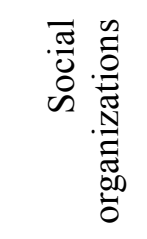 \\
\hline Promoter & & * & $*$ & & $*$ & & & & * \\
\hline Coordinator & & * & $*$ & & $*$ & & $*$ & & * \\
\hline Developer & & * & * & & & & & & \\
\hline
\end{tabular}




\begin{tabular}{|c|c|c|c|c|c|c|c|}
\hline Consultant & $*$ & & $*$ & $*$ & & & $*$ \\
\hline Advisor & & & & & $*$ & & \\
\hline Ambassador & $*$ & $*$ & $*$ & & $*$ & * & \\
\hline Educational leader & $*$ & $*$ & $*$ & $*$ & $*$ & & $*$ \\
\hline
\end{tabular}

\section{The counselor as promoter of service-learning}

As Nelson (2007) points out, school counselors can act as facilitators of the service-learning program and ask interested teachers, staff, and parents to help them implement the program. To. The counselor is, therefore, perceived as a facilitator of ideas and teamwork.

"[..] I see myself in the role of facilitator, promoter, researcher, because I read things, I keep on learning, and I provide that motivation [..]" (Counselor).

Meanwhile, teachers emphasize the importance of the innovative nature of the counseling department, which has to do things in a different way and make things better for students. At the same time, social entities emphasize the role of the counselor in encouraging teachers to include service-learning in their subjects as a way of connecting with the community. Therefore, it is an initiative and a proposal to respond to emerging needs.

"I would say the Counseling Department is the seed (...), but it has managed to extend it to the whole center (...) This innovative manner, the spirit of doing things differently and making things better for students [..]" (Teacher involved in servicelearning_7).

\section{The counselor as another teacher using service-learning}

Teachers, families, and the counselor himself see him as another teacher using a didactic methodology in the classroom, implementing service-learning in the subjects that he teaches.

"[..] When I'm on a project as a teacher of a subject, [..] it is more or less the same the same (as any other teacher) [..]" (Counselor).

"[..] As a teacher of Citizenship Education, he starts it there in the second year of compulsory secondary education; he implements it there [..]" (Teacher involved in service-learning _1).

\section{The coordinating role as a link between the school and the community}

Among all the activities involved in the role of coordinator, its specification as a link between the school and the community is particularly relevant in the discourse of teachers, students, and social entities. The counselor works with each partner organization and performs tasks related to mediation and to the transfer of information. In the students' words, he acts as "common thread". In this regard, the counselor is the point of entry for the community partners to the school, as the first steps for the implementation of service-learning by teachers require the input of the counselor.

"[..] He exercises the task of transfer of information or connection between all projects, or between the city council and us [..]" (Teacher involved in service-learning $5)$.

"He is a coordinator and a link between the various entities involved in the process: 
institutions, municipal office of information on volunteering, tutors, teachers, students" (Teaching staff_3).

\section{The advisory role in service-learning in terms of collaboration}

This advisory work is seen by teachers as collaborative consultation, information exchange, facilitation, and support. The counselor is perceived as a professional with knowledge and experience in counseling, and able to provide answers in the form of suggestions, guidance, procedures, or materials.

"[..] In my case, as a counselor, you accompany, same as you accompany tutors or students, and you give them the opportunity to participate, but in a way that it also brings them along, by showing them that it's something possible, simple and very concrete [..." (Counselor).

"[..] It's very easy to organize work with him, because he simplifies it; that is, you don't feel that you're throwing yourself into the unknown; you're not worried about how you do this now::: but he gives you guidelines, he guides you [..]" (Teacher involved in service-learning_3).

\section{Advisor on service-learning}

Of particular interest in the results of this research is the finding of the role of advisor, as an expert, supporting students who are participating in service-learning activities. For students, the counselor is the person who knows about service-learning and, therefore, who can help them develop it.

"In the end, he has the knowledge, yeah [..]. He can help us to cope, to::: It depends on what kind of service-learning we are going to do, and he can advise, and if something goes wrong, he helps because [..] "(Student_2. Senior High School).

\section{Ambassador of service-learning and counseling}

As regards the counselor, the role of ambassador materializes through activities of support and advice to other schools, participation in awards, dissemination of activities through conferences and talks, and the use of technology for disseminating the servicelearning program. The counselor is very involved in promoting service-learning and the activities of the school, even though he states that this task is time consuming. Moreover, he believes that this aspect needs be improved. This is confirmed in the discourse of other informants, who highlight the development of these activities in collaboration with other participants as a key feature in service-learning.

"[..] I think it's hard for us. Let's say that the hardest part is dissemination. The counselor is more dynamic about this. So, it's true that the issue of dissemination is a substantial part of some service-learning projects, and those are the ones that have the most presence, right? but for me::: I don't have time for everything" (Teacher involved in service-learning_4).

"[..] there are people who know him. This year he has given a talk there, at Margarita High School, I think. There were also people who went to see him, and yes, he is becoming well known. But not so much, that is, he should be better known" (Family_1). 


\section{Educational leader on service-learning}

The results of this research identify the role of the school counselor as the educational leader in service-learning, as he plays a key role in the implementation and development of service-learning projects. This is reflected in the discourse of the counselor, who specifically emphasizes this role, and also in the discourse of the teachers, principal, students and community partners.

"[..] The role of the counselor in the Miguel Catalán High School is essential. If we talk about leadership, obviously the counselor is one of the people who assumes pedagogical leadership in the school [..]" (Principal).

"[..] He is like the heart, right? He's the one who pumps the blood. Also, he has, the counselor has extraordinary talent to move masses. The counselor is extraordinary in that sense, [..] he's able to involve a lot of people" (Teacher involved in service-learning_4).

"I think that he is the centerpiece, who motivates and interrelates all of us who are going to work with him. For me, he is the centerpiece" (Social organization_2).

The counselor emphasizes his interest in the development of this role from a collaborative approach of "shared leadership".

"[..] That role of leadership is played by [..], I play it here, but it also [..] has been a focal point on certain projects, and that's what I call shared leadership, and that's what I'm interested in" (Counselor).

\section{Discussion}

In this paper the perception of the relationship between service-learning and school counseling is based on the role of the counselor. This is in line with Nelson's (2007) arguments, as he points out that, as an intervention, service-learning is a smart option for developing counseling programs at school.

The counselor establishes the connection between service-learning and his functions to the extent that it is a "tool" for developing them, especially those activities that are related to coexistence and intervention in the community. Social entities consider service-learning as a strategy that facilitates the organization of the work of the counselor. Moreover, for the teacher, the relationship between service-learning and the counselor is based on their perception of the counselor as an advisor, promoter, and coordinator of the development of proposals in the school. In the same vein, students and families highlight his role as facilitator and advisor in the development of the projects. All this allows us to conclude that school counselors have the potential to work globally, improving the educational experiences of students through servicelearning programs (Nelson, 2007).

The findings on the roles of the counselor concur with the points made by various authors (Boza Carreño et al., 2009), in the sense that the counselor develops multiple roles. In line with that, as has been stated in the theoretical framework, there is a wide range of literature and research on the development of the functions and the role of the counselor, but we have not found any references that address these roles in specific school practices, as discussed in this study, which aims to understand the roles developed by the counselor regarding service-learning in a secondary school.

The counselor plays an important role in promoting service-learning in a school. This professional is considered key in the implementation of service-learning through dissemination, 
organization, planning, and management activities. This premise is framed by the perception of the counselor as a change agent (Bolivar \& Romero, 2009; Calvo et al., 2012; Domingo Segovia, 2004; Hervás Avilés, 2006; House \& Hayes, 2002; Martínez Garrido et al., 2010; Santana Vega, 2010).

We agree with Spring, Grimm and Dietz (2008) that coordination is key in service-learning, as it involves technical support and assistance in activities with the community. According to Sala Silvera (2011), the teaching role of the counselor should not be neglected or discarded, but should be part of the counselor's activity as a way to keep in touch with reality and with the difficulties in the process of learning and the challenge of teaching; that is, delivering lessons.

This work confirms the counselor's established role as advisor. The results show that in this secondary school, he is an advisor in terms of collaboration for the implementation and development of service-learning, along the lines identified by the literature (Alvarez \& Bisquerra, 1996; Vázquez Weapons, 2012; Bisquerra, 2012; CIDE, 2009).

Of particular interest in the results of this research is the identification of the role of the counselor as an expert in assisting students who are participating in service-learning activities (Carreño Boza et al., 2009; CIDE, 2009).

The role of ambassador of service-learning and counseling is taken on as the development of the role of representative of the school to the outside, and the point of contact with public and private institutions (municipalities, associations, NGOs). However, unlike Boza Carreno et al. (2009), who consider that this role is not much appreciated by practitioners, the results of this study show that this role is appreciated and relevant for the development of service-learning.

As noted in the theoretical framework, there is a variety of literature on the role of the counselor as a leader, defender, and promoter of change in the school (Amatea \& Clark, 2005; Anderson, 2010; Bolivar \& Romero, 2009; Boza Carreño et al., 2009; Calvo et al., 2012; Clark \& Amatea, 2004; Curry \& DeVoss, 2009; Domingo Segovia, 2004; Gairín Sallán \& Moreno, 2008; Martínez Clares, 2010; Martínez Garrido et al., 2010).

The results of this study allow us to position the counselor of the featured secondary school in the role of educational leader in service-learning, with a key role in the implementation and development of these projects from a collaborative approach with other educational agents. This is in line with Wilczenski and Coomey's (2007) arguments, which state that counselors and teachers working together can positively influence the lives of students in their social, emotional, professional, and academic development through initiatives such as service-learning.

\section{Conclusion}

In this research, school counseling is a way of personalizing education, a process of help, support, and advice for the overall development of students, as well as an element of quality, educational improvement, and social justice. In this context, the school counselor plays a relevant role in promoting and developing methodological proposals that educate in values and competencies of participation and social responsibility, such as service-learning.

The clear relationship between service-learning and school counseling is evidenced to the extent that this methodology is part of the counseling action as agent of change and social justice. In this context, the counselor is considered a promoter and advisor in the development of service-learning. Also, he is perceived as one more teacher who uses the service-learning methodology in his subjects, promotes confidence, and strengthens the development of these projects in the school. The coordination task carried out by the counselor is highlighted as a link between the different resources that are launched, as well as the relevant role as ambassador of the service-learning program. All this within the counselor's position of pedagogical leadership, considered key in proposals for innovation and improvement in the school.

The pedagogical leadership is based on a model of collaboration and teamwork that enables not only the implementation but also the development and sustainability of the program, while it accommodates the provision of counseling and advice to students.

This study corroborates the position of Steen and colleagues (2012), who highlight the relevance of counselors in programs such as service-learning, which are aimed at achieving the 
objectives of schools and communities.

Finally, this work offers the opportunity to learn from the experience of an educational center that is a benchmark in the use of service-learning, and in which the counselor plays a key role in its implementation, development, and sustainability. This implies assigning school counseling and its development in a secondary school of an innovative character from a social perspective, with emphasis on promoting values of participation and citizenship, that are necessary for learning and for academic, personal, and social achievement.

In this regard, we conclude with the words by Lovat and Clement (2016, p. 125):

"The globe that point to the inextricability of values as being at the heart of good practice pedagogy and, within that, the especially potent force that service learning can impel around all of the goals of education, including those pertaining to personal and social development as well as to academic achievement".

\section{Authors' Note}

García-López, María Lourdes. Departament of Didactics and Theory of Education, Autonomous University of Madrid; mlgarcialop@educa.aragon.es

Aramburuzabala, Pilar. Departament of Didactics and Theory of Education, Autonomous University of Madrid; pilar.aramburuzabala@uam.es

Cerrillo, Rosario. Departament of Didactics and Theory of Education, Autonomous University of Madrid; charo.cerrillo@uam.es

\section{References}

Álvarez, M. \& Bisquerra, R. (1996). Manual de Orientación y Tutoría. Barcelona: Wolters Kluwer.

Amatea, E. S. \& Clark, M. A. (2005). Changing schools, changing counselors: A qualitative study of school administrators' conceptions of the school counselor role. Professional School Counseling, 9, 16-27. doi:http://dx.doi.org/10.5330/prsc.9.1.w6357vn62n5328vp

Anderson, K. L. (2010). Culturally considerate school counseling. Thousand Oaks, CA: Corwin.

Aramburuzabala, P., Cerrillo, R. \& Tello, I. (2015). Aprendizaje-servicio: Una propuesta metodológica para la introducción de la sostenibilidad curricular en la universidad. Profesorado. Revista de Currículum y Formación del Profesorado, 19(1), 78-95. Retrieved from: http://bit.ly/1UHzkQ8

Armas Vázquez, D. M. (2012). El rol del orientador en el siglo XXI. ACLPPinforma, 27, 12-15. Recuperado de http://bit.ly/1Pkuwfl

Bisquerra, R. (2012). Orientación, tutoría y educación emocional. Madrid: Síntesis.

Blakey, J. M., Theriot, S., Cazzell, M. \& Sattler, M. (2015). Is service-learning worth it?: A mixed-methods study of Faculty's Service-Learning experiences. International Journal of Research on Service-Learning and Community Engagement, 3(1). Retrieved from: http://journals.sfu.ca/iarslce

Bolívar, A. \& Romero, C. (2009). El asesoramiento y la mejora escolar. In C. Romero (Ed.), Claves para mejorar la escuela secundaria (pp. 137-152). Buenos Aires: Noveduc.

Boza Carreño, A., Toscano, M. \& Salas, M. (2009) ¿Qué es lo que hace un orientador?: Roles y funciones del orientador en educación secundaria. Revista de Educación, 9, 111-131. Retrieved from: http://bit.ly/1WIGnLZ

Calvo, A., Haya, I. \& Susinos, T. (2012). El rol del orientador en la mejora escolar. Una investigación centrada en la voz del alumnado como elemento de cambio. Revista de Investigación en Educación, 10(2), 7-22. Retrieved from: http://webs.uvigo.es/reined/

Celorrio, R. (2004). Rol del orientador psicopedagógico en los centros de educación secundaria. In I Jornadas Universitarias JUTEDU 2004. Competencias Socio-profesionales de las 
Titulaciones de Educación, UNED 29-30 octubre. Retrieved from: http://www2.uned.es/jutedu/CelorrioRafael-IJUTE-Comunicacion.PDF

Centro de Investigación y Documentación Educativa (CIDE). (2009). Orientación educativa: fundamentos teóricos, modelos institucionales y nuevas perspectivas (2nd ed.). Madrid: Ministerio de Educación.

Clark, M. A. \& Amatea, E. (2004). Teacher perceptions and expectations of school counselor contributions: Implications for program planning and training. Professional School Counseling, 8(2), 132-140. Retrieved from: http://bit.ly/1YfljvV

Curry, J. \& DeVoss, J. (2009). Introduction to special issue: The school counselor as leader. Professional School Counseling, 13, 64-67.

Dockery, D. J. (2011). A guide to incorporating service learning into counselor education. Retrieved from: http://bit.ly/1Y9h4Sv

Domingo Segovia, J. (2004). El psicopedagogo como asesor interno en los procesos de mejora cualitativa de los centros educativos. In J. M. Moreno (Coord.), Organización y gestión de centros educativos (pp. 365-388). Madrid: UNED.

Domingo Segovia, J. (2006). Los departamentos de orientación en la mejora cualitativa de la educación secundaria. Revista de Educación, 339, 97-118. Retrieved from: http://www.revistaeducacion.mec.es/re339/re339a07.pdf

Domingo, J., Fernández, J. d. D. \& Barrero, B. (2014). La función de asesoría para la mejora de la enseñanza y el aprendizaje en la práctica profesional de un orientador de zona. Un estudio de caso. Educatio Siglo XXI, 32(1), 151-172. Retrieved from: $\mathrm{http} / / /$ revistas.um.es/educatio/article/view/194131

Eyler, J., Giles J. D. E. \& Braxton, J. (1997). The impact of service-learning on college students. Michigan Journal of Community Service Learning, 4, 5-15. Retrieved from: de http://hdl.handle.net/2027/spo.3239521.0004.101

Gairín Sallán, J. \& Moreno, J. L. M. (2008). El agente de cambio en el desarrollo de las organizaciones. Enseñanza \& Teaching: Revista Interuniversitaria de Didáctica, 26, 187206. doi: http://dx.doi.org/10.14201/et

Hernando, A. \& Montilla, C. (2009). El estudio de los roles y funciones de los orientadores de secundaria utilizando la técnica de los grupos de discusión. Revista Española de Orientación y Psicopedagogía, 20(1), 29-38. Retrieved from: http://bit.ly/1YlY3g5

Hervás Avilés, R. M. (2006). Orientación e intervención psicopedagógica y procesos de cambio. Granada: Grupo Editorial Universitario.

House, R. M. \& Hayes, R. L. (2002). School counselors: Becoming key players in school reform. Professional School Counseling, 5, 249-261.

Jett, S. T. \& Delgado-Romero, E. A. (2009). Prepracticum service-learning in counselor education: A qualitative case study. Counselor Education and Supervision, 49(2), 106-121.

Loizaga, F. (2005). Departamentos de orientación: Un análisis del rol orientador y de las nuevas figuras asesoras. Revista Española de Orientación y Psicopedagogía, 16(1), 47-61.

Retrieved from: http://bit.ly/1ZIzXL5

Lovat, T. \& Clement, N. (2016). Service Learning as Holistic Values Pedagogy. Journal of Experiential Education, 39(2) 115-129. doi: 10.1177/1053825916628548

Lucas, S. \& Martínez Odría, A. (2012). La implantación y difusión del aprendizaje-servicio en el contexto educativo español. Retos de futuro de una metodología de enseñanzaaprendizaje para promover la innovación en la educación superior. Revista del Congrés Internacional de Docència Universitària i Innovació, 1(1), 1-14.

Martínez Clares, P. (2010). La orientación en tiempos de cambio. In J. J. Maquillón (Coord.), La formación del profesorado en el siglo XXI: Propuestas ante los cambios económicos, sociales y culturales (pp. 45-63). Murcia: Editum.

Martínez Clares, P. \& Martínez Juárez, M. (2011). La orientación en el siglo XXI. Revista Electrónica Interuniversitaria de Formación del Profesorado, 14(1), 253-263. Retrieved from: http//www.aufop.com

Martínez Garrido, C. A., Krichesky, G. J. \& García Barrera, A. (2010). El orientador escolar como agente interno de cambio. Revista Iberoamericana de Educación, 54, 107-122. Retrieved from: http://rieoei.org/rie54.htm 
Murillo, F. J. \& Krichescky, G. J. (2012). El proceso del cambio escolar. Una guía para impulsar y sostener la mejora de las escuelas. Revista Iberoamericana sobre Calidad, Eficacia y Cambio en Educación, 10 (1), 27-43. Retrieved from: http://www.redalyc.org/pdf/551/55123361003.pdf

Nelson, J. (2007). The top ten things school counselors and school administrators should know about service-learning. International Journal of Educational Leadership Preparation, 2(1) Retrieved from: http://eric.ed.gov/?id=EJ1066777

Noreña, A. L., Alcaraz-Moreno, N., Guillermo, J. \& Rebolledo-Malpica, D. (2012). Aplicabilidad de los criterios de rigor y éticos en la investigación cualitativa. Aquichan, 12(3), 263-274. Retrieved from: http://www.scielo.org.co/pdf/aqui/v12n3/v12n3a06

Puig, J. M., Batlle, R., Bosch, C. \& Palos, J. (2007). Aprendizaje servicio. Educar para la ciudadanía. Barcelona: Octaedro.

Sala Silvera, J. M. (2011) ¿Da clase el orientador? ACLPPinforma, 22, 13-15. Retrieved from: http://dialnet.unirioja.es/servlet/articulo? codigo $=3631010$

Santana Vega, L. E. (2010). Orientación educativa e intervención psicopedagógica: Cambian los tiempos, cambian las responsabilidades profesionales (3rd ed.). Madrid: Pirámide.

Simons, H. (2011). El estudio de caso: Teoría y práctica. Madrid: Morata.

Sobrado, L. M. \& Sanz, R. (1998). Roles y funciones de los orientadores. Revista de Investigación Educativa, 16(2), 25-58.

Smith-Tolken, A. \& Williams, J. (2011). Service learning: Innovations for the next decade. Oral communication presented at Service Learning Research Colloquium. Stellenbosch, 20-21. Retrieved from: http://bit.ly/1WIHZ8s

Spring, K., Grimm, R. \& Dietz, N. (2008). Community service and service-learning in america's schools. Corporation for National and Community Service. Retrieved from: http://1.usa.gov/1PPR4u7

Steen, S., O'Keefe, A. L., Griffin, D. \& Routzahn, K. (2012). Service-learning and classroom guidance: A program for elementary students. Journal of School Counseling, 10(2). Retrieved from: http://1.usa.gov/1YibVrK

Stelzer, T. (2003). A critical analysis of the function of guidance counselors. University of Wisconsin-Stout, Wisconsin. Retrieved from: http://bit.ly/1PPXxFr

Wilczenski, F. L. \& Coomey, S. M. (2007). A practical guide to service learning: Strategies for positive development in schools. New York, NY: Springer Science \& Business Media. 